\title{
THE ROOTS OF THE PORTUGUESE COMMUNIST PARTY. THE INTRODUCTION OF MARXIST IDEAS IN PORTUGAL AND THE CREATION OF THE PORTUGUESE MAXIMALIST FEDERATION
}

\author{
LAS RAÍCES DEL PARTIDO COMUNISTA DE PORTUGUÉS. \\ LA INTRODUCCIÓN DE LAS IDEAS MARXISTAS EN PORTUGAL \\ Y LA CREACIÓN DE LA FEDERACIÓN MAXIMALISTA PORTUGUESA
}

Adelino Cunha*

Universidade Europeia, Lisboa, Portugal

IHC - NOVA FCSH, Universidade NOVA de Lisboa, Portugal

\begin{abstract}
This article is divided into three complementary parts. Firstly, an analysis of the introduction and dissemination of Marxist ideas in Portugal is put forward to assess the dynamics that led to their political territorialisation through the creation of the Portuguese Maximalist Federation (FMP) in 1919. How did these ideas penetrate into the public space and which mechanisms led to their diffusion from the intellectual circles? Secondly, the contents of the newspaper A Bandeira Vermelha are analysed to assess its role in this dissemination and its importance in the subsequent process of the establishment of the Portuguese Communist Party (PCP) in 1921. What were the main ideas disseminated by the maximalists' official propaganda body and what was its impact on the spreading of Marxism? Finally, this article puts into perspective the importance of the newspapers $O$ Comunista and Avante! in the dissemination of Marxist ideas and their impact on the complex and lengthy process of the PCP's Bolshevisation.
\end{abstract}

KEYWORDS: Portuguese Communist Party, Portuguese Maximalist Federation, Marxism, Bandeira Vermelha, O Avante, O Comunista.

RESUMEN: Este artículo está dividido en tres partes complementarias. En primer lugar, se realiza un análisis de la introducción y difusión de las ideas marxistas en Portugal para evaluar las dinámicas que llevaron a su territorialización política a través de la creación de la Federación Maximalista Portuguesa.; Cómo penetraron estas ideas en el espacio público y a través de qué mecanismos? ¿Se difundieron? En segundo lugar, se estudian los contenidos del periódico A Bandeira Vermelha para evaluar su papel en esta difusión y su importancia para el posterior proceso de establecimiento del Partido Comunista Português. ¿Cuáles fueron las principales ideas difundidas por los maximalistas y cuál fue su impacto en la difusión del marxismo? Para finalizar, el artículo sitúa en perspectiva la importancia de los periódicos O Comunista y Avante! en la difusión de las ideas marxistas y su impacto en el complejo y largo proceso de bolshevización del PCP.

PALABRAS CLAVE: Partido Comunista Português, Federação Maximalista Portuguesa, Bandeira Vermelha, O Avante, O Comunista.

* Correspondence to: Adelino Cunha. Universidade Europeia, Quinta do Bom Nome, Estrada da Correia, 53 (1500210 Lisboa) - adelino.cunha@universidadeeuropeia.pt - http://orcid.org/0000-0002-9502-7913

How to cite: Cunha, Adelino (2020). "The Roots of the Portuguese Communist Party. The Introduction of Marxist Ideas in Portugal and the Creation of the Portuguese Maximalist Federation»; Historia Contemporánea, 64, 883-918. (https://doi. org/10.1387/hc.20729).

Received: 2 April, 2019; Accepted: 17 September, 2019.

ISSN 1130-2402 - eISSN 2340-0277 / (C) 2020 UPV/EHU 


\section{Introduction}

Little was known about Marxist ideas in Portugal. At the end of the $19^{\text {th }}$ century and the beginning of the $20^{\text {th }}$ century, only the meaning of the «revolution taken to its maximum» was known. There were ignorance and confusion. Most of the studies analysed and compared in this article identify the 1917 Russian revolution as a turning point, given that it created a certain need, also in Portugal, of a revolutionary force organised as a political party.

This force was only waiting for an opportunity to be materialised, insofar as it already demonstrated some social existence. António Pedro Pita summarises that «Although dispersed [...] it would be indispensable to provide it with theoretical and organic cohesion so that it could be the voice of a popular will still without political expression» 1 .

This force would be the Portuguese Communist Party, which was to be founded in 1921 .

The process underwent successive refluxes and projected beyond the so-called 1940-41 reorganisation ${ }^{2}$. This may be justified by the weaknesses found, first, in the reception of ideas that were limited to the restricted intellectual circles, and then, in its complex practical shape through a party born of the overhasty labour movement and anarchist activism.

The process of penetration of Marxist ideas in Portugal was, therefore, slow and complex, having known a first acceleration precisely through the projection of the real success embodied by the Russian revolution. Bento Gonçalves ${ }^{3}$ even announces retroactively «a new history» that had opened up for humanity to then exalt Russia as «the most alive, epic and exciting example that proletariat will defeat bourgeoisie» ${ }^{4}$.

It is still a peripheral knowledge, centred on the dimension of intellectual discourse.

This explains the difficulties both in disseminating these ideas and in their subsequent process of assimilation by a political force organised as a party: César Oliveira alerts that «The lack of knowledge about the role of

${ }^{1}$ Pita, 1994, pp. 89-108.

2 The chronological span of this article ends with the arrest of Bento Gonçalves in 1935, after having implemented the first major reorganisation of PCP.

${ }^{3}$ Bento Gonçalves was secretary-general of PCP between 1929 and 1942, the date of his death in the Tarrafal prison camp.

${ }^{4}$ Gonçalves, 1976, pp. 119-157. 
the Bolshevik party and Leninism may explain much of the confusion» ${ }^{5}$. Bento Gonçalves himself translated Bolshevism as «the revolution taken to its maximum».

The establishment of the Portuguese Maximalist Federation (FMP) in 1919 is the first attempt to organise workers into political structures outside the logic of unions, that is, the embryo of a party shaped to fully represent Marxist ideas and lead the political struggle for their fulfilment.

Unlike what happened in other European countries, Marxism did not come into Portugal through the door of the Socialist Party, largely because this party had plunged into a «reiterated ineffectiveness ${ }^{6}$ and had long held a strong «frailty and institutional weakness» ${ }^{7}$. In these countries, the communist parties emerged from splits caused in the socialist parties affiliated to the II International: «In Portugal, the establishment of PCP is due to the efforts of some revolutionary unionists, anarchists and anarchist-unionists», in the words of César Oliveira ${ }^{8}$.

Socialism was discredited and unable to attract militants who wished to intervene in society with the legitimate expectation of a radical change. The glow of the early years of the Republic had been lost ${ }^{9}$. «The Socialist Party did have neither significant social implantation, nor its creative internal dynamics, nor did it, as a left-wing party, have enough «strength» to generate an alternative from within in face of the real workers' movement», César Oliveira sums up ${ }^{10}$.

\section{The introduction of Marxist ideas in Portugal}

It is important to bear in mind that «until around 1930, the basic doctrinal reference for Portuguese communists is, strictly speaking, Bolshe-

5 Oliveira, 1975 , p. 30.

6 Pita, 1994, pp.89-108.

7 Which reinforces «the profoundly national nature of the communist movement in Portugal», as advocated by João G.P. Quintela, who adds: «This is how all the first militants and journalists who complained about the «Bolshevik» stances have a history of known unionists and proletarian fighters», Quintela, 1976, pp. 7-8.

8 Oliveira, 1975, p. 17.

9 At the congress of May 1911, for example, 91 associations, with a total of 35,000 members, were represented. This was the most representative workers' assembly held until then. Cfr. Ventura, 2000, p. 220.

${ }_{10}$ Oliveira, 1975, p. 17-18. 
vism and not quite Marxism», as António Pedro Pita alerts ${ }^{11}$. This devaluation of the theoretical dimensions clearly hindered «the influx of Marx's thought in Portugal» and limited both the PCP's Bolshevisation and its actual implementation in the party organisation.

The first reference to Karl Marx in the public sphere identified in Portugal took place on February 7, 1874, at a conference that took place at the Institute of Coimbra on the initiative of José Frederico Laranjo: «[It is] the first attempt to explain its theoretical stance, based on the reading of The Capital» ${ }^{12}$, Alfredo Margarido writes.

It is a rhetoric exercise, circumscribed to a certain intellectual elite.

António Pedro Pita anticipates this first contact in a slightly different way. The author maintains that «Marx was spoken among us since the middle of the $19^{\text {th }}$ century», and cites, in particular, the year 1852 , when the Coimbra magazine $O$ Instituto publishes an article on a «controversy aroused by Proudhon's work Philosophy of misery, to which Marx, as is known, replied with Misery of philosophy» ${ }^{13}$.

The truth is that the few texts on Marx and Marxism circulated timidly among the intellectuals, being used basically in pamphlets or low-impact works, such as, for example, the studies of Guilherme Alves Moreira (1891), António Augusto Pires de Lima (1899-1900) and Basílio Teles (1901) ${ }^{14}$.

This circumscription may be explained more by the low levels of literacy in the country and less by the intrinsic value of the ideas and the value of their dissemination ${ }^{15}$.

In 1912, the first attempt to partially translate The Capital emerges, on the basis of the summary published by Gabriel Déville in 1883. Despite the shortcomings, it was «for a long time Marx's only existing text in Portugal, or even in the Portuguese language», Alfredo Margarido alerts. António Pedro Pita sustains that «only in 1975 will there be a new edition, after (in January) 1974, the full Portuguese publication (by Vital Moreira and Teixeira Martins) was started, which was incomplete» ${ }^{16}$.

11 Pita, 1994, pp. 89-108.

12 Margarido, 1976, p. 54.

13 Pita, 1994, pp. 89-108.

14 Castro, 1993, pp.16-27, cited in Pita, 1994, pp. 89-108.

15 Margarido, op. cit, p. 32, alerts that «If the publications of Marxist theorists were already extremely few in countries with literate and urbanised population, they were practically impossible among us».

16 Pita, 1994, pp. 89-108. 
César Oliveira adds three translations of Marxist works and some texts of the journal $O$ Instituto de Coimbra to state that «the knowledge of Marxism in Portugal was, after all, extremely low» ${ }^{17}$.

The dissemination of Marxist ideas occurred slowly after this somewhat dispersed beginning. João G.P. Quintela highlights that «During an initial period, 1917-1918, there is the utmost confusion and a lot of misunderstandings: the militants are lost in the acronyms and in Russian political mainstreams ${ }^{18}$.

The newspaper $O$ Século began to publish some articles from 1919 onwards, but the first biography of Marx emerged only in 1930 by the hand of the anarchist-unionist Emílio Costa. This biography, as António Pedro Pita points out, «seems to reveal substantial ignorance of the work of The Capital's author, which is detectable in the over-simplification of the German thinker's contribution» ${ }^{19}$. The Manifesto Comunista would only be published in $1925^{20}$, which leads, to some extent, César Oliveira to write that the penetration of Marxist ideas was «extremely piecemeal» and with obvious theoretical weaknesses.

The perception of the poor theoretical preparation and the ignorance of the role of the Bolshevik party and of Leninism is common ${ }^{21}$.

Marx and Engels' ideas and theses were thus «introduced without giving rise to the establishment of parties or groups with the aim of practising any Marxism», Alfredo Margarido explains. The author sums it up effectively: «Four years after the proclamation of the military and fascist dictatorship, the door closes on the work of Marx, not by the grace of the dictatorship, but by the firm and heavy hand of an anarchist-unionist militant whose devotion to the cause had always known no limits»22.

It is acceptable, as Bento Gonçalves points out, that the sympathy for the Russian revolution was not «determined by the knowledge of Marxism». In fact, «the strategy and tactics of Lenin's Party were also unknown». In a word, «There was much confusion about the greatest historical event in the life of mankind».

\footnotetext{
17 Oliveira, 1975, p. 30.

18 Quintela, 1976, p.9.

19 Pita, 1994, pp. 89-108.

${ }^{20}$ Quintela, 1976, p. 67.

21 Oliveira, 1975, p. 30.

22 Margarido, 1976, p. 10.
} 
Did people know enough? People knew the etymological meaning of the word Bolshevik. People thus knew to link its meaning to the «revolution taken to its maximum» ${ }^{23}$.

Alfredo Margarido states that Marxist ideas were introduced «slowly and insufficiently». The author adds that «Marx and Engels' ideas and works were imported, translated, disseminated, not by socialists or by «Marxists», but simply by anarchists. This was the case in Italy, and this was also the case in Portugal» ${ }^{24}$.

The difficulty in welcoming Marxist ideas is also demonstrated in Antonio Pedro Pita's works: «Its dissemination among the workers' movement and among socialist intellectuals was difficult [...] and slow». The author adds that «only from 1919 onwards does the socialist movement embody the lessons of the October revolution» 25 .

This reality was necessarily reflected in the first attempts to introduce, and then consolidate, Marxism on the basis of the new political organisations, that is, on the late organisation of the unionised proletariat into a new party.

\section{The singularities of the emergence within the union movement}

This raises, from the outset, an additional question: why have Marxist ideas triumphed in Portugal among unionists, anarchists and anarchist-unionists, clearly overshadowing socialists?

According to João G.P. Quintela, it was precisely this past of struggle in the union movement that enabled the Bolshevik option, that is, a «continuation of the previous struggle that they had led in favour of the «advanced» ideas» ${ }^{26}$. The concept of the dictatorship of the proletariat and the promise of a radical shift in social organisation represented an «enrichment». Alfredo Margarido also refers to «a political reality that required unprecedented solutions» ${ }^{27}$, but João G.P. Quintela goes further by adding that it results from «the fruit of the maturation of the radicalisation process».

\footnotetext{
23 Gonçalves, 2000, p. 82.

24 Margarido, 1976, p. 10.

25 Pita, 1994, p. 4.

26 Quintela, 1976, pp. 8-9.

27 Margarido, 1976, p. 89.
} 
César Oliveira's understanding follows that of the other authors, and adds the politicised dimension to differentiate the two levels of struggle: «Only the class revolutionary political organisation duly articulated with the union organisation and envisaged by the revolutionary theory can, in the different phases of the class struggle, explore the totality of contradictions in the bourgeois society in order to conquer for the exploited and oppressed new stages of awareness, organisation and class position that allow new advances in the revolutionary struggle ${ }^{28}$.

This particular feature would justify, from the outset, a comparative perspective with the creation of the Spanish Communist Party (PCE).

The existence of a split between the Spanish socialists in the establishment of PCE marks a difference with the Portuguese experience, but there are proximities to explore regarding the pivotal importance of the union movement and the anarchist-unionism in the establishment of PCE. This led Guy Hermet to write that (also) PCE was born «impregnated» by the anarchist and anarchist-unionist tradition ${ }^{29}$. Moreover, Victor Alba would later draw the attention to this «double origin» ${ }^{30}$, pointing to a (desirable) comparison between the roots of PCE and PCP on the basis of the experience of revolutionary syndicalism, anarchism and anarchist-unionism.

It seems to us that this compared perspective of the roots of Iberian communism remains unaccomplished and that it must now also include the foundational processes of the French and Italian communist parties. The task of the literature review is eased by the developments in academic research on French, Italian, and, more recently, Spanish communism ${ }^{31}$.

In his specific study on the forms of territorial organisation of the Partit Socialista Unificat de Catalunya [Unified Socialist Party of Catalonia] (PSUC) during the fight against Francoism, Giaime Pala cites congresses, works and studies that indicate the updating of knowledge about communism in Spain, asserting that these works developed during the last decade have allowed to «remarkably improve» the knowledge about the political culture, the militant practices and the communist ideology, especially during Francoism ${ }^{32}$.

\footnotetext{
28 Oliveira, 1975, p. 25.

29 Hermet, 1967, p.2.

30 Alba, 1979, p. 17.

31 Bueno y Gálvez, 2005, pp. 317-322.

32 Pala, 2015, pp. 195-222.
} 
In the same period as the publications of seminal authors in Portugal, the work of Rafael $\mathrm{Cruz}^{33}$ also offers a global and dynamic view of PCE during the II Republic. This is also an unavoidable work in the area of communism studies. The role played by official propaganda in the mobilisation of the Spanish communists could be addressed here, but this article focuses on the foundational roots, that is, they are different chronological periods $^{34}$.

However, this differentiation clearly benefits from a comparative perspective when using an interpretative framework that can frame the two Iberian sections, for example, the origins of the sections of the Communist International ${ }^{35}$. It is thus clear that PCE results from a break with socialists, contrary to what happened with $\mathrm{PCP}^{36}$.

In fact, studies addressing the emergence of European communist parties as Moscow's «political branches» are especially relevant for validating comparisons, for example, the relationships of the Portuguese and Spanish communists with the Communist International and the guiding role played in each of the two cases by Moscow.

The same occurs with the common mental framework that marked the imaginary ${ }^{37}$ of the Portuguese and Spanish communists in the founding processes of their parties, as it results, to a great extent, from the first news about the Russian revolution that arrived in the Iberian Peninsula and the subsequent travels of the first leaders to the «homeland of socialism» ${ }^{38}$.

33 Cruz, 1987.

34 A comparison, not of the ideological origins, but of the early party structures could benefit from the article «La organización del PCE (1920-1934), Estudios de historia social, no. 31, 1984, pp. 223-312.

${ }^{35}$ Cruz Martinez, 2007.

36 Cf. pp.12-13.

37 The representations resulting from these conversions can be seen in Farré, 1999, and Elorza, 1999. The authors address in detail the «religious» dimension produced with the advent of the Russian revolution, i.e., the interpretation of communism as a «new faith» of a secular nature. Cf. also Cruz Martinez, 1984, pp. 55-63.

38 This «revolutionary hope» is very much present in the various studies published within the scope of the 100 years of the Russian revolution, for example: Gutiérrez-Álvarez, 2017; Andrade, 2017. 


\section{The Portuguese Maximalist Federation}

FMP was founded in September 1919 by «many of those who, in Portugal, in the adverse post-war context, did not accept the impasses and limitations of traditional union action» ${ }^{39}$, rather than as a consequence of some maturation of the process of Marxist ideas' welcome, César Oliveira alerts. The author also maintains that it was a group of «very few militants», which did not call into question the dominant power of union organisations: «They are not, in fact, the forefront of a real and global alternative arisen within the Portuguese labour movement ${ }^{40}$.

Manuel Ribeiro took up the position of secretary-general and the management of Bandeira Vermelha ${ }^{41}$, and brought a large group of unionists with him $^{42}$. It is precisely these unionists who will overtake the union movement itself, which was at a relapse due to the failure of the general strike attempt in 1918, and showed difficulties in addressing the worsening of the class struggle resulting from the end of the $\operatorname{war}^{43}$.

FMP defined the path of insurrection towards the take-over of power, using the first issue of its official media body to take on the goal of «spreading the doctrinal principles tending to the establishment of the communist unionism, admitting temporarily the action of the revolutionary power exercised in dictatorship by the workers' councils or Soviets» (Article 1).

It is added that both the dictatorship of the proletariat and the Soviets should be regarded as «sheer experimental practices» (Article 2), ending with the assurance that their action «will be exercised in principle and normally in the legal doctrinal field» (Article 3$)^{44}$.

João G.P. Quintela identifies in a «very clearly» way the «mark of anarchism» and cites as an example the defence of the combination of the idea of revolution with local economic conditions, complementing with the presentation of a sample of the topics addressed by Bandeira Ver-

39 Madeira, 2013, p.17.

40 Oliveira, 1975, p. 26.

${ }^{41}$ In its first four issues, the newspaper is called A Bandeira Vermelha. From no. 5 onwards (November 1, 1919), the heading mentions only Bandeira Vermelha.

42 António Peixe, Paulo Luíz, Clemente Vieira dos Santos, Marcelino da Silva, Francisco Dias, Arsénio Filipe, Leal Salveda, Luíz Larangeiro, José da Silva Oliveira, Gonçalves Correia, J. Luíz do Nascimento, cf. J.P. Quintela, 1976, p. 13.

${ }^{43}$ Quintela, 1976, p. 14.

44 «Estatutos da Federação Maximalista Portuguesa», A Bandeira Vermelha, no. 1, October 5, 1919; A Bandeira Vermelha, no. 14, January 4, 1920. 
melha and their citations: «If we find 27 anarchist authors cited in the newspaper, the number of Marxists does not exceed $15 \gg^{45}$.

José Pacheco Pereira recognises these marks as resulting from the fact that recruitment was made «fundamentally in the anarchist milieus, in the provincial circles, in the radicalised sectors, more in ideological than in social terms» ${ }^{46}$.

The declaration of principles itself expresses many of the ideological misconceptions, reaffirming that «all components of FMP and its councils are, in principle, anarchists and revolutionary unionists, although they have taken on the designation of Bolsheviks, communists, maximalists or Sovietists». The justification has a rather puerile tone: «Or any other [designation] that the State picks on ${ }^{47}$.

Faced with the need to explain the meaning of being Bolshevik, the maximalists pleaded the workers: «Bolshevik, affirm yourselves, in the streets, in the public squares, in the face of the great and the powerful, before the authorities and the potentates. State that being a Bolshevik is being for the poor and against the rich ${ }^{48}$.

These misconceptions result from two foundational problems.

On the one hand, they result from the ideological frailties of its members due to the limited impact of Marxism among Portuguese intellectuals and the scarcity of information and dissemination sources. This leads Alfredo Margarido to assert that «in 1919 there were no Communists in Portugal, let alone Bolsheviks, but simply anarchist militants and revolutionary unionists» ${ }^{49}$. In other words, poor information and the influence of revolutionary and anarchist unionism hindered «the correct understanding of the true meaning of the Soviet revolution and its importance to the international labour movement ${ }^{50}$.

On the other hand, they result from the growing doubts expressed by the anarchists and unionists regarding the creation of a political party inspired by a revolution that, in Russia, eliminated the anarchists and promised a model of power based on the dictatorship of the proletariat ${ }^{51}$. Add-

45 Quintela, 1976, pp. 18-19.

46 Pacheco Pereira, 1981, pp. 695-713.

47 «Declaração de Princípios», A Bandeira Vermelha, no. 2, October 12, 1919.

48 «Pelo Bolchevismo!», A Bandeira Vermelha, no. 3, October 19, 1919.

49 Margarido, 1976, p. 88.

50 Ventura, 1977, pp. 10-12.

51 The studies unanimously point to a majority of anarchists. 
ing to this was the need of the maximalists of this demarcation: «Unions have to deal not only with the immediate issue, which takes a lot of time from them, but also with the technical-professional issue of production, which is the most important for the Revolution. They cannot, therefore, prepare the revolutionary act or conduct it, although, after it has been carried out, they are the economic bodies of the newly established state $\gg^{52}$.

According to João Madeira, these weaknesses in no way deprive FMP of what was new about it: «[Open] in the Portuguese labour movement another pole, which affirmed precisely the insufficiency of a union organisation, a new social order in itself $\rangle^{53}$, that is, the change promised by the Russian revolution, going beyond the dynamics of unions.

The study by José Pacheco Pereira also points in this direction, that FMP «provided the way of entry for the communism of some former anarchists» ${ }^{54}$, while César Oliveira alerts that its action «was virtually limited to the publication of Bandeira Vermelha» ${ }^{55}$, which is in line with Bento Gonçalves' stance, who had limited the FMP's work to the publication of Bandeira Vermelha as a shy attempt to approach the ideas of the Russian revolution, but «in a confused way» ${ }^{56}$.

The maximalist theses designed by Bandeira Vermelha, which adequately represented the spirit of the time, are a meeting point for all the revolutionaries who sought to overthrow the bourgeoisie through violent means ${ }^{57}$. Using a certain narrative drama, João G.P. Quintela tries a synthesis on this regrouping of the revolutionaries, which seeks to match a «hegemony project» characterised as follows: «Extra-union organisation, violent takeover and dismissal of the bourgeois State, establishment of the dictatorship of the proletariat and the Soviets» ${ }^{58}$.

The undeniable organic weakness was reflected, from the outset, in the «geographic over-concentration», which was almost exclusive in Lisbon and Porto. This lack of a national dimension strongly limited the

52 «In order to prepare and carry out the Revolution, a strong extra-union body of a proletarian and revolutionary nature is indispensable», Bandeira Vermelha, no. 11, December 14, 1919.

${ }_{53}$ Madeira, 2013, p. 18.

54 Pacheco Pereira, 1981, pp. 695-713.

55 Oliveira, 1975, p. 35.

56 Gonçalves, 2000, p. 83.

${ }^{57}$ In the case of the Portuguese Maximalist Federation, it is more about verbal violence, that is, an inflamed narrative practice that did not translate into concrete acts.

${ }^{58}$ Quintela, 1976, p. 16. 
FMP's social capacity of penetration, inasmuch as only five maximalist councils operated in the capital and one communist centre operated in the North. João G.P. Quintela sustains that, despite these difficulties, FMP had supporters in the province, in the colonies and in some emigration circles $^{59}$.

The truth is that there was now a new way forward. Alfredo Margarido concludes that «The maximalist militants knew the situation of the working class very well, almost all were workers, and they could not think of creating a Bolshevik party with the Bolsheviks that did not exist» ${ }^{60}$.

This party would arrive soon.

\section{The importance of the publications}

Writing aimed to «spread the sacred fire of rebellion by the crowds». Writing aimed to «tear down the bourgeoisie» and less about «saturated philosophies». The analysis of the impact of Bandeira Vermelha reveals that this dissemination of Marxist ideas emerged at a later stage of the publications.

The first maximalists still consider themselves anarchists, thus translating the difficulties of the very process of creation of the Portuguese Communist Party (PCP).

This was due, firstly, to its small dimension ${ }^{61}$; secondly, to the peripheral position within the international communist movement; but above all, and lastly, to the specificities stemming from the unionist and anarchist roots.

For this reason, the process of establishment of the first political frameworks took place under adverse conditions and was strongly dependent on the traditional communication tools at the time, that is, flyers, leaflets and the regular party press.

59 The social composition of the Federation can be consulted in the study by Quintela, based on the profile of the Bandeira Vermelha authors. This allows indirectly attesting the «proletarian and popular nature of the Federation», op. cit., pp. 20-21.

60 Margarido, 1976, pp. 88-89.

${ }^{61}$ José Pacheco Pereira reports the existence of about 1,700 PCP militants in 1921, the highest number recorded during the I Republic, cf. Pereira, 1981, pp. 695-713. João G.P. Quintela mentions a similar number by the end of the following year, but it regards militants with paid fees, and refers to a total of 2,900 militants, cf. Quintela, 1976, p. 48. 
The Russian revolution had a number of favourable publications in Portugal, such as A Sementeira, A Batalha and A Aurora Social, among many others, but Bandeira Vermelha stands out as «the pioneer of the media bodies that, in our country, defended the ideals of the October revolution» António Ventura assures, adding that «It is the first press body of an organisation that inscribes in its program not only the defence and dissemination of the October ideals but also the struggle for some of these objectives» $^{62}$.

FMP's official media body began its circulation on October 5, 1919, left the circulation on December 5,1920, and returned to a second period that lasted until June 1921. Its founders include prominent unionists, such as Manuel Ribeiro, António Peixe, Paulo Luís, Arsénio Filipe and Luís do Nascimento. The suspension was precisely the result of the political repression that led to the arrest of Manuel Ribeiro ${ }^{63}$.

According to António Ventura, between the extinction of FMP and the establishment of PCP, on March 16, 1921, Bandeira Vermelha assumed as its communication body «until the emergence of the official body of that party», that is, until the emergence of no. 1 of the weekly newspaper $O$ Comunista, on October 16, $1921^{64}$.

It would again be Manuel Ribeiro who took over these functions as editor-in-chief during the seven issues published until November 27, 1921, «to better fit into the objectives of the III International» ${ }^{65}$.

In its first issue, Bandeira Vermelha defines as its goal «to prepare the environment to destroy the bourgeois organisation and to create a proletarian power that hastens the evolution of the peoples from the capitalist phase to the socialist-communist phase» ${ }^{66}$.

But what is the real meaning of these words when the maximalists (still) see themselves as anarchists?

«We the anarchists» must «spread among the crowds the sacred fire of upheaval» because the working masses «are becoming sick and tired

62 Ventura, 1977. pp. 10-12.

${ }^{63}$ Following his release in April 1921, Bandeira Vermelha was to return episodically on April 17, 1921.

64 The brief study by António Ventura reveals the existence of other publications, but of markedly little importance; for example, the publication of the Portuguese Esperantist Communists, Komunist-Esperantista Grupo, with only an issue in July 1921; O Alarme, published in Coimbra between July 31 and August 15, 1921 (three issues).

65 The suspension lasted until May 1923.

66 «Os nossos objectivos», A Bandeira Vermelha, no. 1, October 5, 1919. 
of philosophies». The same narrative lightness that refuses the dictatorship of the proletariat: «As anarchists, we do not accept dictatorship in principle, as it is the true denial of libertarian principles». And that accepts it at the same time: «We are in favour of the Dictatorship of the Proletariat and we deem absolutely indispensable that all anarchists are» ${ }^{67}$.

This (poorly solved) issue often emerges on the pages of the newspaper. This shows its controversial nature and a simultaneous inability to explain: «The [dictatorship] of the bourgeoisie is that of a minority in its sole advantage; that of the proletariat is that of the majority for the benefit of the whole society and is a means, never an end» ${ }^{68}$.

This is an issue that regularly emerges on the pages of Bandeira Vermelha: «The revolutionary problem» ${ }^{69}$.

An interview with Trotsky published in the newspaper Chicago Daily News will feature headline honours with considerable photographic prominence. It is important for Bandeira Vermelha, as it states that «the dictatorship of the proletariat, I can assert, is almost entirely a consequence of the war that moves us. We consider this dictatorship as purely temporary. As soon as the conflict is over, freedom of the press will be restored, as will all other freedoms ${ }^{70} \gg$.

The explanations are often directly transcribed from statements or excerpts from interviews.

The British newspaper Daily Herald is cited to seek for the meaning of the Soviets: «They are more than a parliament. A parliament only legislates. The Soviets legislate and manage [...] But what is particularly interesting is that the mandate of the deputies to the Soviets can be revoked by a vote of their voters. It is true democracy ${ }^{71}$.

Simplification repeats, but the effort to meet a concrete need for Bolshevisation should be highlighted ${ }^{72}$.

67 «Os anarquistas e a ditadura do proletariado», Bandeira Vermelha, no. 5, November $1,1919$.

68 «Ditadura e ditadura», Bandeira Vermelha, no. 8, November 23, 1919.

69 «Em volta do problema revolucionário - A nossa ditadura», Bandeira Vermelha, no. 40 , August 1,1920 .

70 «Ditadura «temporária» do proletariado», Bandeira Vermelha, no. 14, January 4, 1920.

71 «Como funcionam os sovietes», Bandeira Vermelha, no. 13, December 28, 1919.

72 Filipe Nunes Carvalho timely notes that «until no. 19 the MFP symbol (a fist raising a fiery blade) appears in the heading, which, in a significant shift of the importance of 
After regretting that «some Portuguese unionists, perhaps because they were not at all aware of the Soviets' structure and functioning, or because they were attached to old dogmatic and confused formulas», one of the writers essays the defence of representativeness criteria in unions, having as examples the Russian Soviets, and, as the source of this knowledge, Pelloutier's book: «Our unionist Bible» ${ }^{73}$.

This is a remarkable fact that reflects a certain urgency of learning and that starts to have an answer with the direct sale of several books through the pages of the newspaper ${ }^{74}$, as well as the publicity of the works that arrive in Portugal on the Russian revolution, together with brief explanatory notes. The titles reflect a clear concern with the dissemination of the Bolshevik success, but also with the understanding of the underlying dynamics and ideas themselves. In turn, the pedagogical success should be put into perspective.

As a rule, the pages of Bandeira Vermelha display a confused rhetoric that generically sought «to defeat the privileges and supremacies of the ruling classes; to give back the worker the product of his/her labour by socialising all the wealth; to subject the bourgeoisie to the compulsory labour regime; to provide social care to minors and underprivileged citizens, and to radically eradicate the cancer of prostitution, as was done in Russia, these are the cornerstones of our revolutionary program» ${ }^{75}$.

The contradictions persist with the positioning of the «ideal of Bolshevism» in economic federalism affiliated with anarchism: «The

the diffusion of the October revolution ideas to the organisation, is replaced by the representation of a sickle and a hammer surrounded by the caption «Republic of the Soviets», in: «Bandeira Vermelha, órgão da Federação Maximalista (1919-21)», cf. Carvalho, 1983, pp. 6-13.

73 «Agitando ideias - Sovietismo e sindicalismo», Bandeira Vermelha, no. 6, November 9,1919 .

${ }^{74}$ The Bandeira Vermelha's library starts to publish works by P. Kropotkine, Dufour, Gorki, J. Grave, E. Zola, Hamon, Tolstoi, Antonelli and A. Del Vale. Also noteworthy are the works by Manuel Ribeiro himself $O$ Sentido de Viver, Na Linha de Fogo and Imperiosa Verdade, and, finally, Marx's Capital. An effort that is also identified in the publications of Editora Popular, whose advertisement provides six works of the social propaganda collection, for example, A Constituição Política da Repúblicas dos Sovietes, A Moral Anarquista, A Rússia Nova and A Greve Geral, and anticipates the edition of other collections.

75 «Os objectivos da Revolução», Bandeira Vermelha, no. 11, December 14, 1919. 
Soviets' ideal is a federation of peoples freely linked by economic relationships ${ }^{76}$.

The ideological struggle is centred on the propaganda rhetoric, and the generality of the efforts of theorising fades into semantics.

During the year 1920, Bandeira Vermelha reports in an isolate way events of an international nature, having as aggregator an idea of siege to Bolshevism and the corresponding «titanic struggle» of the Bolsheviks from all these countries ${ }^{77}$. An editorial line is reinforced with panegyric articles on the triumphs of the Soviets and with a reference of ideological issues to the secondary pages ${ }^{78}$.

It remains to be known whether this diminishing of the debate results from a certain perception by the maximalists of having overcome the initial ideological difficulties, or only from a discursive normalisation: «Bolshevism is neither socialism nor anarchism but it is near one and the other, collecting from all the energy needed to move forward» ${ }^{79}$.

In the information sessions used for the «war on the bourgeoisie», the maximalists emphasise two critical issues: the need to bring about an «immediate armed revolution» and to establish a «dictatorship of the proletariat». Bandeira Vermelha follows the violent rhetoric: «No agreements with the bourgeois. Whoever is for us comes to us. A revolution which is not uprooted, which is not nobly conquered by the proletariat in arms, is not a complete revolution nor does it give the right to demand everything ${ }^{80} ;$ «To bring down the bourgeoisie is a sacred duty. One does not debate with the enemies of the people: they are executed ${ }^{81}$; $«$ Social transformation is not carried out through pacifisms ${ }^{82}$; $\langle$ Struggle, fight to the last bullet, to the last drop of blood» ${ }^{83}$.

76 «The attitude of the Soviets' government. The ideal of Bolshevism is economic federalism such as anarchism», Bandeira Vermelha, no. 11, December 14, 1919.

77 «O Bolchevismo triunfante», Bandeira Vermelha, no. 18, February 1, 1920.

78 For example: «A Obra económica dos Soviets da Russia», Bandeira Vermelha, no. 20, February 15, 1920; «O esforço dos bolchevistas em prol da instrução do povo», Bandeira Vermelha, no. 21, February 22, 1920; «Os Soviets na Alemanha - A Revolução Social em marcha!», Bandeira Vermelha, no. 26, March 28, 1920; «A voz da América», Bandeira Vermelha, no. 28, May 9, 1920; «A Revolução social na Alemanha», Bandeira Vermelha, no. 28, May 9, 1920.

79 «Bolchevismo e Anarquismo, Bandeira Vermelha, no. 20, February 15, 1920.

80 «Caminho a seguir», Bandeira Vermelha, no. 25, March 21, 1920.

81 «Palavras claras», Bandeira Vermelha, no. 27, May 2, 1920.

82 «Devemos precipitar a Revolução», Bandeira Vermelha, no. 36, July 4, 1920.

83 «Às armas», Bandeira Vermelha, no. 37, July 11, 1920. 
The approaches of a pedagogical nature become less frequent.

The communist regime is dissected by explaining the creation of the Russian Soviets ${ }^{84}$, Bakoukine ${ }^{85}$ and Kropotkine ${ }^{86}$ are used to account for episodes of the social revolution; the reproduction of Lenin's documents is also used so that readers can feel the «beating of the same spirit of revolt, the same flame of Lenin's rebellion» ${ }^{87}$.

When it comes to explaining the political options, the maximalists justify adhesion to Bolshevism as «a moral issue»: «If we are, therefore, in favour of the immediate revolution and consequent use of the proletarian dictatorship, it is because we are horrified to see the growth of the misery of the peoples and, more than the misery, the moral rot».

\section{The idea of a political party}

The idea of creating a party that would incorporate these Bolshevik values and assume the political organisation of the proletariat for a violent take-over of power starts to increasingly emerge in the pages of Bandeira Vermelha.

This is (still) an untimely appeal of the author to the transformation of Bolshevism into a doctrine of salvific nature, and with an extra-party projection: «Bolshevism has already left the restricted scope of a political party to become a social tendency» ${ }^{88}$. The desire was temporarily suspended in the lines written by Manuel Ribeiro: «The need of a convention or understanding between all the political and social currents that predominate in the working environment in Portugal».

Bandeira Vermelha begins to repeat gradual calls for the establishment of a committee in Lisbon and another in Porto «to organise a communist congress in the shortest possible time» ${ }^{89}$.

84 «O regime político comunista - O que é um soviet?», Bandeira Vermelha, no. 29, May $16,1920$.

85 «Bakoukine e a revolução social», Bandeira Vermelha, no. 31, May 30, 1920.

86 «Caminhamos para a revolução», Bandeira Vermelha, no. 35, June 27, 1920.

87 «A Carta de Lenine ao operariado inglês», Bandeira Vermelha, no. 33, June 13, 1920.

88 «Porque somos bolchevistas», Bandeira Vermelha, no. 41, August 8, 1920.

89 «Porque não se fez ainda um Congresso comunista em Portugal?», Bandeira Vermelha, no. 43, August 22, 1920. 
This idea of establishing a communist party emerges clearly in $\mathrm{Au}-$ gust 1920, through the proposal to create an aggregating congress of unionists and anarchists.

It is again the feeling of change of the political structures that emerges, mobilised by the idea of «maximum utility»: «We must put aside the comforts that have held us back so much [...] [to] organise the dispersed forces, turning them into a power, in short, to establish our front» ${ }^{90}$.

The idea evolves significantly with Bandeira Vermelha advocating in an increasingly explicit way the creation of a new party: «The communist organisation in Portugal must be carried out as soon as possible!» ${ }^{91}$.

The exclamation expresses the feeling of some urgency, justified with the danger of demobilisation of the maximalist militants.

It is time now to «organise a powerful and disciplined political force that attacks, in its foundations, the bourgeois-capitalist domination», that is, «organise the communist family across the whole country» and thus mobilise «sincere and unpretentious wills, which, although divided, wait, burning in the inveterate belief of an egalitarian future».

The expression of this will begins to be designed as a proposal that, although it does not yet expressly point towards the creation of a party, is clear in its purposes of mobilisation towards new forms of political organisation: «We propose to bring together so many efforts scattered out there».

The proposal starts to be favourably welcomed by some union sectors, particularly among young people, and the Union of Youth Unionists of Portugal expressed its support early.

It is an «idea underway!», the maximalists reply ${ }^{92}$.

They take up the struggle for the organisation of the first communist congress with the involvement of unionists, anarchists «or socialists», in order to unify the «militant proletariat» in what they classify as a «work of conciliation».

However, times are changing and, for the first time, the maximalists materialise the great goal of this desired congress: «If the communist party came out of this congress organised in solidarity, with the fusion of

90 «A máxima utilidade», Bandeira Vermelha, no. 48, September 26, 1920.

91 «Organisemos o Comunismo em Portugal», Bandeira Vermelha, no. 48, September 26, 1920.

92 «Uma ideia em marcha!», Bandeira Vermelha, no. 50, September 10,1920. 
all ideological tendencies, as was done in Spain, Italy and other countries, perhaps we could form a gigantic block».

The demonstration of this maturation is reflected in the associated propaganda rhetoric, inasmuch as the maximalists plan the creation of the communist party as a historical responsibility.

After a few months of suspension due to Manuel Ribeiro's arrest, Bandeira Vermelha is published again and assumes the irreversibility of the creation of the «Portuguese Communist Party» ${ }^{93}$.

This was due, on the one hand, to the fact that «the modern revolutionary tactics [...] materialises in the so-called Communist Parties» that are «a new arrangement of active values, a new disposition of the revolutionary hosts for the final decisive battle». On the other hand, to the fact that this tendency was already, also in Portugal, «embodied in the soul of a large part of the Portuguese proletariat».

The maximalists claim that, at this time, there is already a Communist Party in Portugal, «although in embryo».

\section{The birth of PCP}

On March 21, 1921, PCP was officially born. It was born of the impulse of «a dozen revolutionaries and union militants» ${ }^{94}$ who considered that «the revolution [in Portugal was] inevitable» ${ }^{95}$.

Shortly before, on December 12 of the previous year, the first attempt to create a new political organisation outside the union space had taken place at the headquarters of Associação de Classe dos Caixeiros de Lisboa (Class Association of Lisbon Clerks). The disagreements between maximalists, anarchists and unionists had slowed this impulse, but during the same month of December, an agreement was reached for the setting up of a Workers' Organising Committee for the Constitution of the Communist Party.

Between January and March of the following year, the principles, objectives, functioning bases and leaders of the new party were approved. Among the first communists, as João Madeira describes, «the maximal-

\footnotetext{
93 «Ressurgindo», Bandeira Vermelha, no. 55[54], April 17, 1920.

94 O Comunista, no. 1, October 16, 1921.

95 Pacheco Pereira, 1999, p.62.
} 
ists, with a quite insignificant number of socialists and some former republicans ${ }^{96}$ stood out.

The founding of PCP represents a sign of concrete hope for those in favour of the «immediate revolution», as Bento Gonçalves claims.

The founding reflected the need to organise the masses through the dialectical unity between theory and practice, but César Oliveira imposes some caution: «Although it is in line with the action of the Portuguese Maximalist Federation, [the founding of PCP] does not result from the organisational growth of this organisation nor does it correspond to the increase of its influence of masses». The author also adds that «the militants who found the Portuguese Communist Party are very few and illprepared $\gg^{97}$.

The founding principles were embodied in the organic bases, being the «supreme goal» to materialise a «revolutionary action made timely by the circumstances of the European and national milieu», that is, «the full socialisation of the means of production».

The leadership was initially handed over to a National Board composed by Alberto Júlio das Neves, Bernardino dos Santos, Fernando Barbosa, João Nascimento Cunha and Caetano de Sousa. This body was supported by a General Committee of Education and Propaganda and an Economic Council, with nine and seven members respectively ${ }^{98}$. On the party base, there were four communist centres, located in Lisbon, Porto, Santarém and Évora ${ }^{99}$. The official press body, O Comunista, began its

${ }^{96}$ Madeira, 2013, p. 20.

97 Oliveira, 1975, pp. 35-36.

98 The unionist José de Sousa forced a breakdown in the Socialist Youth to create the Communist Youth with some of its leaders. In 1922, he moved to the collective leadership of PCP. The creation of the Communist Youth benefited from this split, and from the same manoeuvre with the unionists. It is important to take this into account, in the sense that these militants took into PCP much of their social and political radicalism that characterised the whole phase that precedes the rise of Bento Gonçalves: violent street actions and ideological inconsistency.

99 José Pacheco Pereira explains that these communist centres worked as «political clubs based on members», which made it difficult for PCP to grow and consolidate as a party, insofar as «they were only going to attend the propaganda sessions». This situation changed partially after the 1923 Congress, through the creation (forced by the Communist International) of administrative-based communes to enable the participation in the elections. These structures eventually transformed into cells, but the neighbourhood or even street organisational genetics was kept», cf. Pacheco Pereira, 1981, pp. 695-713. 
circulation in October of that year, under the management of Manuel Ribeiro, Nascimento Cunha and Caetano de Sousa ${ }^{100}$.

According to José Pacheco Pereira, «more than former anarchists or anarchists-unionists, PCP's founders and main activists are unionists, either active at the time of the Party's life or former union leaders of the generation formed in the 1910-12 struggles and of the immediate post-war period», that is, «being part of FMP is not, in terms of union and political path, the most characteristic biographical feature of most Party members, but rather union activism» ${ }^{101}$.

\section{The narrative surpluses}

PCP's specific roots were soon expressed: «An organisation called the Portuguese Communist Party was founded in Lisbon, whose directive is not yet well defined, since within it there are the most bitter partisans of the Dictatorship of the Proletariat and the most fervent supporters of the Anarchic Communism» ${ }^{102}$, Bandeira Vermelha announces.

This leads José Pacheco Pereira to classify PCP as «a very peculiar organisation, which hardly fit the Leninist model of organisation, being a kind of anti-anarchist republican radical party, acting in the union milieu, but neglecting the parliamentary «politics» and the endemic conspiracy disease of the I Republic» ${ }^{103}$.

The first crisis occurred shortly after and forced the constitution of a reorganising committee between March and October 1921. At the basis, a rupture between left and right, or rather between the workers and the employees: «Here may be the root of the accusations made by «bourgeois» addressed retrospectively to the members of the Party in the I Republic» ${ }^{104}$, the same author continues.

The divergences forced the intervention of the Communist International in $1922^{105}$.

\footnotetext{
100 Quintela, 1976, p. 43.

101 Pacheco Pereira, 1981, pp. 695-713.

102 «O que penso do Partido Comunista», Bandeira Vermelha, no. 63, June 19, 1921.

103 Pacheco Pereira, 1999, p. 63.

104 Pacheco Pereira, 1981, pp. 695-713.

105 Quintela, 1976, pp. 50-70.
} 
The first direction, which had succeeded the organising committee of the founding, falls at this time. José Pacheco Pereira speaks of a «purge» process of that initial steering group, «whose nature of effective leadership of the Party was virtually non-existent» ${ }^{106}$.

The struggle for power forced the I (Legal) Congress to take place in November 1923. Humbert-Droz intervened to force PCP to adopt relative normality through the constitution of a first party structure and the definition of political orientation. It is interesting to note, in the memoirs of Jules Humbert-Droz ${ }^{107}$, how, in his role as a discreet «head of the clandestine orchestra» ${ }^{108}$, he decisively influenced the evolution of the Latin parties in a pivotal period of the international communist movement ${ }^{109}$ and played a key role in both Iberian sections ${ }^{110}$.

The nominal power was delivered to Carlos Rates ${ }^{111}$.

Alfredo Margarido classifies him as «the first militant to question Karl Marx's theoretical proposals as a tool for political work» ${ }^{112}$, but his influence was «short-lived», as António Pedro Pita points out ${ }^{113}$.

In his analysis of the PCP's founding features, Rates begins by clarifying the withdrawal of the Socialists, highlighting the "profound anaemia of efforts, will and revolutionary awareness» of the Portuguese Socialist Party 114 .

Carlos Rates is, then, carried away by a generous narrative fluctuation to criticise the anti-parliamentary stance adopted by PCP at the founding: «A nonsense that needs to be amended». He suggests that the party «ac-

106 Pacheco Pereira, 1981, pp. 695-713.

107 Humbert-Droz, 1971.

108 Stdourdzé, 1973, pp. 196-199.

109 Stanek, 1972, p. 425.

110 He came to Portugal several times to intervene directly in PCP since the establishment and throughout the whole stage of organic and ideological consolidation, cf. p. 24.

111 Carlos Rates served in the navy, worked in the cannery industry of Setúbal and became secretary-general of the city's Unions Movement in 1911. He joined the so-called worker-farmer brigades from the following year onwards and developed intense union propaganda activity all over the country. He stood out in the 1914 National Workers' Congress and was among the main unionists of the Portuguese labour movement, cf. Quintela, Para a história..., p. 68. He eventually became a «pro-fascist», a corporate official and member of the National Union, cf. Oliveira, 1975, p. 36.

112 Margarido, 1976, p. 81.

113 Pita, 1994, pp. 89-108.

114 «O Partido Comunista - Causas da sua constituição e seus objectivos», Bandeira Vermelha, no. 55, April 24, 1921. 
cepts the parliamentary struggle» so as not to become another of the «fake fires that left no trace of their passage», and also because it is «in Parliament [that] there is opposition and it is this that should be established and developed».

He then reminds that the maximalists had emerged to «propagandise the Bolshevism of the popular masses» and thus became «modestly» a «sheer grouping of hardworking militants». PCP represented a new stage through its main objective: «To adapt the nation to the new regime of proletarian institutions, successor to the rotten and weakened bourgeois system» ${ }^{115}$.

Manuel Ribeiro showed the same rhetorical flexibility by placing PCP between the union movement and the exercise of executive power: «The Portuguese Communist Party is either parliamentary or ceases to be a party», seeking to explain that, by nature, «it should act with some elasticity, outside the rigid dogmatism of theories and schools». After stating that «we do not want to cooperate, we want to sweep», he asserts that «if the communist Parties aim at the conquest of power by the working class, and if the parliament is the main headquarter of power and a vulnerable point of bourgeois governments [...] it is only logical that the communists should go struggle in the parliament».

Rates also questions the power of union organisations to bring about radical political and social change, even if he does that in ambiguous ways. First, he assumes the «deficiency of the union organisation» and its «limited sphere of action», but warns that «he would have preferred to extend the action and directive of the union organisation».

Manuel Ribeiro is clearer, treating the Confederação Geral do Trabalho (CGT) as a «neutral and colourless body of professionals and workers, with no political creed that does not allow it to have its status or any other program than the abolition of wages and emancipation from employers»116.

The following years were very heavy. «No communist work was carried out during the whole period until 1927», João G.P. Quintela claims, clarifying: «Rates is an appointed leader, not a regularly elected leader;

115 «O Partido Comunista Português ou é parlamentar ou deixa de ser um partido», Bandeira Vermelha, no. 59, May 22, 1921.

116 «O Partido Comunista Português ou é parlamentar ou deixa de ser um partido», Bandeira Vermelha, no. 59, May 22, 1921. 
the party, either does nothing or is lagging behind the bourgeoisie» ${ }^{117}$. José Pacheco Pereira accuses him of having thought of himself as «the Portuguese Lenin» ${ }^{118}$.

This heaviness left a heavy legacy: «Our Party is still weak. Weak in numbers and weak in ideology» ${ }^{119}$.

\section{The ups and downs of $O$ Comunista}

Bandeira Vermelha published its last issue in June 1921 and, in October, $O$ Comunista began its first period of existence as the PCP's official press body. The first issue begins by assuming that the founding of PCP results from the will of «a dozen revolutionaries and union activists» and clarifies that «it is far from being a dissidence in the former militants of the proletariat» 120 .

Communists fully assume the need for the proletariat to be organised through a new party structure of a revolutionary nature, bearing in mind the very limitations of the union movement, but they make little progress with regard to the Bandeira Vermelha's rhetoric: «PCP seems to have inherited both the contacts and the implementation of the former Maximalist Federation as its ideological ambiguities», João GP Quintela claims ${ }^{121}$.

The growth of PCP would have to be done at the expense of the union movement, and criticism of its leaders emerges in the pages of $O$ Comunista: «The facts force us to acknowledge its revolutionary incapability; it is its lack of idealism. And without idealism, there is no faith, there is no enthusiasm, there is no revolution» ${ }^{122}$.

In order to have a revolution, it was necessary to have PCP.

Furthermore, unionism was exhausted: «It was great hope in the soul», but the time had come for communists to carry these flags in their hands. Since «the revolutionary insufficiency of union action [was demonstrated], it is necessary to resort to political action, to party action».

117 Quintela, 1976,p. 57.

118 Pacheco Pereira, 1999, p. 63.

119 «O Partido Comunista perante as eleições - Resolução do Secretariado Político», Avante!, no. 6, series I, July 8, 1931.

120 «Novos Horizontes», O Comunista, no. 1, October 16, 1921.

121 Quintela, 1976,p. 42.

122 «Novos Horizontes», O Comunista, no. 1, October, 1921. 
The idea of the unification of workers on a single revolutionary front meant now to settle the unions in «purely economic» struggles for PCP to take the lead in the political struggle ${ }^{123}$, and PCP would begin to promise the social revolution for «when the time came for the proletariat to act and impose its will» ${ }^{124}$.

Compared with the contents of Bandeira Vermelha, the communist official press body increases the pressure on unions and strongly attacks their leaders. Otherwise, there are not many rhetorical novelties brought by $O$ Comunista. Perhaps the confession of ignorance: «The great social event that took place four years ago in Russia and which has had repercussions in the whole world is still not well understood today by those who are linked to the revolutionary movement» ${ }^{125}$.

The announced self-suspension of the newspaper was declared in November 1921 as a «standstill», having returned in May 1923 and extending its existence until 1926. The new series assumes the need for PCP to train its militants in the spirit of Marxism and clarifies the disagreements with the anarchists. It tries, thus, to define «the role, the place, the conceptions of the party», João Q.P. Quintela summarises, also emphasising the continuity of the effort of demarcation between the Marxist ideas and anarchism ${ }^{126}$.

The II (Legal) Congress, which took place in May 1926, anticipates the disappearance of PCP into illegality.

It is a phase already marked by a mutation of the original matrix, in the sense that there is some generational exhaustion that translates into political practices that are closer to a party and less to the traditional propaganda movements.

It will be necessary to wait for Bento Gonçalves to come to power (in 1928) so that it becomes possible to identify marks of Bolshevisation: «He was the great worker of the Leninist transformation of PCP, that is, of the break with the anarchist-unionist hegemony at the 1929 Conference», António Pedro Pita maintains.

It was necessary to «wake up» PCP. Bento Gonçalves himself would state that this initial phase of the introduction of Marxism was dominated by «theoretical ignorance» ${ }^{127}$.

\footnotetext{
123 «A CGT não é política», O Comunista, no. 1, October 16, 1921.

124 «O momento», O Comunista, no. 2, October 23, 1921.

125 «A filosofia da revolução russa», O Comunista, no. 4, November 6, 1921.

126 Quintela, 1976, p. 58.

127 Gonçalves, 2000, p.83.
} 
His work on the communists' ideological training ${ }^{128}$ was based on the certainty that «until then Marxism was, to a great extent, a neglected doctrine». It was important to fight the «anarchist ideology» and to gain space in the unions' reorganisation: «We are now taken seriously». The understanding of the Marxist ideology took place in practically unexplored territory and Bento Gonçalves materialised the desired unions' reorganisation to overcome what he classified as «anarchist-unionist provincialism» ${ }^{129}$.

At the time of the VII Congress of the Communist International, Bento Gonçalves claims over 400 members spread throughout the most important urban centres, increased influence in companies and in the rural, intellectual and student sectors, and the assurance of an illegal press that allowed regular contact with the masses.

PCP seemed to have become the «Portuguese main force».

João Arsénio Nunes states without hesitation that «the 1929 reorganisation holds a key place in the history of $\mathrm{PCP} \gg^{130}$.

\section{$X$. The times and the meanings of Bolshevisation}

It is not easy to identify with the necessary rigour the moments that define PCP's Bolshevisation. João Q.P. Quintela cites the theorisation developed within the scope of the 1923 congress as the beginning of a process that extends to 1925 , José Pacheco Pereira indicates the start in that year and its conclusion in 1926, whereas João Madeira positions the process after the 1940-41 reorganisation.

João G.P. Quintela suggests a flexible milestone that can be located between the beginning of the publications of the newspaper $O$ Comunista in May 1923 and the I congress in November of that year, that is, a dynamic resulting from the presentation, discussion and approval of the theses.

On the one hand, this suggestion is due to the fact that they exposed «the essence of the thinking and concerns of their authors»; on the other hand, because they have contributed to «training the militants in the spirit of Marxism and of the International, clearly demarcating anarchist posi-

128 João Brito Freire classifies Bento Gonçalves as «the main mentor of the party's «Bolshevisation» in an article entitled with assertiveness, cf. Freire, 1985, pp. 14-21.

129 Gonçalves, 1976, pp. 119-157.

130 Arsénio Nunes, 1981, pp. 715-731. 
tions, guiding the action of the red-unionists, facing the possibility of an Iberian revolution, putting the problems (especially those of the alliances policy) of the revolution in Portugal, in short, clearly defining the party's role, place, ideas» ${ }^{131}$.

The author further ensures that, at this point, «PCP begins very clearly its Bolshevisation», insofar as, after the congress, it began to develop «an intense political activity». He sustains his interpretation in the creation of the group of the Supporters of the Red Union International in July 1923, the coordination of the establishment of union-revolutionary nuclei in unions and, in 1925, by the decision of the Communist International, the creation of the factory cells ${ }^{132}$.

After emphasising all this «overflowing activity» on the part of PCP, João Q.P. Quintela acknowledges the «obvious ambiguities of the party's line» and cites the contemporary verdict of the Communist International's delegate to PCP: «PCP needs to complete its Bolshevisation and conquer the masses [...] It is necessary that the workers and the farmers see in practice that $\mathrm{PCP}$ is the only defender of their interests» ${ }^{133}$.

In the conclusions of his study, José Pacheco Pereira admits an attempt of «accelerated Bolshevisation» that was «being made» and which was interrupted in 1926: «The military coup and pressure would make the «Bolshevisation» process definitive». He describes this process as «an ideological and political mutation» that foreshadows the new type of militant of the 1930s: still a radical, as was Communist Youth, but willing to replace the debate with discipline and to accept political shifts more easily».

Confronted with Carlos Rates' attempt to transform PCP into an organisation positioned between the union movement and the exercise of executive power, José Pacheco Pereira later asserts that «there is nothing Leninist about these propositions», justifying that this allows understanding «the difficulties of PCP's «Bolshevisation» felt by the first delegates of the Communist International who came to Portugal seeking to shape the «Portuguese section» of the Communist International between 1921 and 1926». The author even labels the PCP leaders of this period as «very bizarre communists» ${ }^{134}$.

131 Quintela, 1976, pp. 62-67.

132 Pacheco Pereira writes that «until the beginning of the 1930s, the prevailing organisational form was at the local, neighbourhood or street level».

${ }_{133}$ H. Dupuy, delegate of the Communist International to PCP.

134 Pacheco Pereira, 1999, p. 64. 
José Pacheco Pereira acknowledges the relevance of the 1940-41 reorganisation in the dynamics of Bolshevisation, justifying that, from that time onwards, the militants began to assimilate the " spirit of the party» and to put PCP «above values of fidelity to the whole of the workers' movement that the militants of the 1920s feared disrespect». He even speaks of the consecration of the «perfect Stalinist» ${ }^{135}$.

Considering that José Pacheco Pereira refers to an «ideological mutation» and João G.P. Quintela to a «political will» ${ }^{136}$, the effort of Bolshevisation that both authors identify has corresponded more to a process of theorisation and less to the implementation of the guidelines in practice, as proposed by the aforementioned delegate of the Communist International. In turn, João Arsénio Nunes highlights the reorganisation of Bento Gonçalves as «the acquisition of an elaborate and homogeneous political awareness - Marxism-Leninism - for the Communist Party» ${ }^{137}$.

In fact, José Pacheco Pereira had already anticipated that «from 1923 onwards» PCP had no basis to be «composed by "notable members" ${ }^{138}$, thus contributing to the picture put forward by Bento Gonçalves in 1929: «The Communist Party does not evidence minimum activity and does not have the slightest influence» ${ }^{139}$.

It was, first and foremost, «a party fundamentally focused on upheaval», João Arsénio Nunes adds, anticipating that, from 1933 onwards, there is a strict implementation of Leninist concepts, «not only in terms of a more realistic definition of the strategic objectives», but also in the organisation: «In addition to defining a strategy for the implementation of the party organisation, the possible structures of the mass direction in the united front work (factory, farms and poor farmers' committees) are also pointed out, as well as those of the connection with the political struggle (anti-fascist struggle committees)» ${ }^{140}$.

João Madeira clearly states that the Bolshevisation process «meant overcoming the sectarian lime, implementing a set of conspiratorial and defensive measures against personal surveillance and repression, improving the proletarian composition of party officials, raising the political

\footnotetext{
135 Pacheco Pereira, 1981, pp. 695-713.

136 Quintela, 1976, p. 74.

137 Arsénio Nunes, 1981, pp. 715-731.

138 Pacheco Pereira, 1981, pp. 695-713.

139 Gonçalves, 1976, p. 9.

140 Arsénio Nunes, 1981, pp. 715-731.
} 
level of the basis, developing a program of publications and of officials' training, strengthening individual discipline and accountability» ${ }^{141}$.

The author presents, as a chronological span, precisely the 1940-41 reorganisation that «led to the building of a new party». More than a diagnosis of the state of the PCP's organisation, it is «a repository of measures to implement the guidelines of the VII Congress of the Communist International».

The beginning will, therefore, correspond to a period of leadership of Júlio Fogaça ${ }^{142}$, which ended with Álvaro Cunhal: «He truly reignites the PCP's Bolshevisation, an extended process but which was sufficiently coherent and rigorous, operated at will».

Bolshevisation thus corresponds to the adoption of the «teachings of organic functioning» of the Communist International adapted to national reality, in particular regarding «vital underground logistic elements» and «conspiracy procedures» imposed on professional revolutionaries. This was a reality designed by Bento Gonçalves during his leadership and which had the pivotal support of a new official press body.

\section{The role of Avante! in PCP's Bolshevisation}

Bento Gonçalves had inherited in 1928 a party which was reduced to «30 Communists» 143 . This leads António Pedro Pita to stress that «between 1928 and 1930, Portuguese communism disconnects from the previous dilution and singles out as a current of opinion and as a political apparatus: it strengthens union influence, increases the number of its members [...], starts the monthly publication of Avante! (1931), broadens its influence in the student and intellectual world» ${ }^{144}$.

PCP began the publication of Avante! in February 1931, which was presented as the central body of the Communist Party, and the Communist Party as the Portuguese section of the Communist International.

141 Madeira, 2004, pp. 507-32.

142 Júlio Fogaça had returned from Tarrafal specifically instructed by Bento Gonçalves to implement a process of deep reorganisation of PCP.

143 Gonçalves, 1976, pp. 119-157.

144 The I Series corresponds to the six issues published between February 15 and July 8,1931 , plus no. 7 of January 1932 and no.9 of January 1933. The II Series began in June 1934 , but only the June, October and November issues were published. Only from January 1935 onwards, Avante! began to be published on a regular basis. 
It is the beginning of the path towards recovery after a long period of darkness. By the beginning of the decade, «the Communist Party was virtually non-existent» 145 .

Avante! emerges already in the shadow of clandestineness and still in the inflamed line of Bandeira Vermelha and O Comunista: «PCP, from this moment on, raises its revolutionary flag, to the rebellion cry of the enslaved masses» ${ }^{146}$.

It is still a revolution without date: «We can no longer continue in the attitude of expectation». It is also a repeat of the attack on anarchist-unionism, but showing increasing signs of change in terms of the approach.

Anarchism begins by being classified as a «theory utterly incapable» ${ }^{147}$ of leading to victory and an «inconsistent and shapeless ideo$\operatorname{logy»}{ }^{148}$, to later evolve within the interpretive framework of a «Bolshevik analysis». In a first moment, the call for mobilisation for «immediate and decisive struggle» remains trapped in the rhetoric of the «most urgent material needs of the proletariat», but there is an evolution in the mental framework: «The proletariat and the farmers of the country must prepare for the establishment of the democratic dictatorship of the exploited workers and the rural masses» ${ }^{149}$.

There is already a discourse about class struggle, mobilisation of the masses, contradictions of capitalism and the need to discuss tactical issues. There is, above all, a discourse about the internal organisation itself, with the aim of conquering new militants to consolidate the influence among the masses: «It is in this sense that the entire Communist Party must be mobilised, from its leadership central bodies to the further located cells of the periphery» ${ }^{150}$.

The theorisation effort is also expressed in the condemnation of the street actions carried out by the upheaval brigades, now considered as a «terrorist deviation». The effort to separate «Bolshevism from terrorism» already allows to cite the concrete example of Lenin's role in the Russian revolution and thus condemn isolated actions: «It is, as Lenin asserted,

145 «A resposta do Partido Comunista Português», Avante!, no. 9, series I, January 1933.

146 «Ao proletariado de Portugal», Avante!, no. 1, series I, February 15, 1931.

147 «O próximo 1. ${ }^{\circ}$ de Maio», Avante!, no. 3, series I, April 16, 1931.

148 «Trabalhadores!», Avante!, no. 4, series I, May 1, 1931.

149 «Situação e tarefas do nosso Partido», Avante!, no. 2, series I, March 1, 1931.

150 «Situação e tarefas do nosso Partido», Avante!, no. 2, series I, March 1, 1931. 
lack of confidence in the insurrection [...] Bolshevism, on the contrary, is class action against class» ${ }^{151}$.

It is a still timid effort because PCP was repositioning itself with the Bolshevisation process which was clearly ongoing: «Let us, hence, leave literature to the care of anarchists and anarchist-unionists and others. For us, a rude language shall be adopted, of true proletarians, as long as it is expressive and sincerely revolutionary» ${ }^{152}$.

The class struggle leads Avante! to also charge on the bourgeoisie: «The little coup d'État has been the ultimate concern, the exclusive delight of the mentors of the petty bourgeoisie». It is the revolution that «frightens them» ${ }^{153}$.

Communists are now steered by a clear objective: «The Communist Party has much more to do than to attract the mass to the true revolutionary path; it is also its duty to enlighten and to lead it. It is its purpose» ${ }^{154}$.

The signs of Bolshevisation emerge early on the pages of Avante! through the first calls for workers to immediately create Factory and Workshop Councils, for farmers to also form their Farmers' Councils and for militaries to organise themselves on Soldiers' and Sailors' Councils ${ }^{155}$.

It is the assumption of the «abandonment of the old methods of revolutionary labour» ${ }^{156}$.

The signs are real and reflect an organisational effort when, for example, the tasks for the cells in factories, considered the «true levers of upheaval», are defined. In the meantime, parallel structures had been created which operated on the peripheries of political activity, such as Federação das Juventudes Comunistas Portuguesas (Federation of Portuguese Communist Youth) and Socorro Vermelho Internacional (International Red Assistance), and control over several unions is already demanded. João Arsénio Nunes adds that «the creation of Comité de Defesa Sindical (Union Defence Committee) and, shortly after, Comissão Inter-Sindical (In-

151 «Bolchevismo e terrorismo», Avante!, no .6, series I, July 8, 1931.

152 «Situação e tarefas do nosso Partido», Avante!, no. 2, series I, March 1, 1931.

153 «A resposta do Partido Comunista Português», Avante!, no. 9, series I, January 8, 1933.

154 «O nosso dia, o nosso dever», Avante!, no. 4, series I, May 1, 1931.

155 «Ao proletariado de Portugal», Avante!, no. 1, series I, February 15, 1931.

156 «Situação e tarefas do nosso Partido», Avante!, no. 2, series I, March 1, 1931. 
ter-Union Committee), which in practice was already a union centre alternative to the anarchist-unionist CGT» ${ }^{157}$.

The coordination of the upheaval work included the creation of leaflets focused on the local fronts of struggle: «The underground central body acts as a coordinator and of a material and ideological basis to assist the cells in the production of their leaflets according to the Party's general line» ${ }^{158}$.

Set aside all the rhetorical surplus, there is a maturation of ideas, clearer from January 1933 onwards: «The analytical and programmatic innovations [...] are profound», João Arsénio Nunes writes, adding that the «intensification» of the «deepening and dissemination effort», resulting from Bento Gonçalves' return to freedom at that time, corresponds to $\mathrm{a}$ «very rigorous understanding of Leninist concepts» ${ }^{159}$.

The Bolshevisation effort is now very clear in the surveillance processes over the detained militants.

PCP begins to «ascertain, from each imprisoned comrade, how far they have brought the revelations to the police, either in their own volition or under the greatest oppression, ill-treatment and agonising beatings», announcing, at the same time, that «all these whistleblowing behaviours» will be «punished» for being «a betrayal of the revolutionary proletariat and its class party - the Communist Party» ${ }^{160}$.

The procedures take shelter on the «Leninist conscience», in search of «the most perfect revolutionary correctness» and the first extreme Bolshevik measures are justified, such as the Secretariat proclaiming «open the broadest criticism and self-criticism in the totality of its officials» and the announcement of the establishment of officials' control committees ${ }^{161}$.

This dynamic inherent to the leadership of Bento Gonçalves will suffer a severe setback with his arrest in $1935^{162}$.

It is not a return to darkness, but the Bolshevisation process will suffer a significant slowdown, whose dynamics exceed the chronological frame justified for this article.

157 Arsénio Nunes, 1996, pp. 22-33.

158 «Situação e tarefas do nosso Partido», Avante!, no. 2, series I, March 1, 1931.

159 Arsénio Nunes, 1981, pp. 715-731.

160 «Comissão Central de Organização do P.C.P.», Avante!, no. 9, series I, January 1933.

161 «Resolução do Secretariado», Avante!, no. 1, series II, June 1934.

162 Bento Gonçalves had been deported in 1930 and returned to the interior in 1933. 


\section{Conclusions}

1. The entry of Marxist ideas in Portugal proved to be a slow and complex process, largely due to the limited knowledge that, for many years, characterised Portuguese intellectuals. The debate was limited in these circles until the news of the success of the Russian revolution motivated a first acceleration, which led to the founding of FMP in 1919;

2. Its founders, who originated directly from unionism and anarchism, took advantage of the limitations of the union movement and began to project into public space the new ideas (many of them wrongfully) which had long circulated more or less everywhere in Europe, but with evident theoretical limitations;

3. The newspaper Bandeira Vermelha became the first great vehicle for the dissemination of the achievements of the Russian revolution and the discursive defence of an identical process in Portugal, but still evidencing the striking lack of knowledge about the fundamental ideas of Marxism which had already occurred among the maximalists;

4. The beginning of the publication of Avante! is a clear breakthrough in the process of bolshevisation. In the short term, due to the decisive contribution to the maturation of Marxist ideas and the concrete orientations for the party organisation and the work with the labour movement. In the long term, because it was published uninterruptedly during the nearly five decades of struggle as an illegal party, being often the only link between the Party and the underground revolutionaries;

5. The consolidation of the Russian revolution led to the need of unifying, in Portugal, the oppositional forces that had hitherto been mixed in the union movement. This need for clarification results in the call for the creation of a political party - the Portuguese Communist Party, two years after the founding of its operational and ideological basis, FMP;

6. The authors of reference in the studies of communism in Portugal are not unanimous about the chronological span when the so-called PCP's Bolshevisation took place, that is, its full maturation as a Marxist-Leninist party. The authors who place the beginning of this process still during the I Republic point either to the flow of the 1923 congress or to the reflux of the 1925-26 crisis. The remaining authors opt for the positive dynamics generated either by the 1929 reorganisation implemented by Bento Gonçalves or by the 1940-41 reorganisation initiated by Júlio Fogaça and concluded by Álvaro Cunhal. 


\section{Bibliography}

AlbA, Victor, El Partido Comunista en España - Ensayo de interpretación histórica, Editorial Planeta, Barcelona, 1979.

Andrade, Juan; Hernández SÁnchez, Fernando (eds.), «1917 La Revolución rusa cien años después», Akal, Madrid, 2017.

ARSÉNIO NuNES, João, «A formação da estratégia antifascista (1929-1935)», História, no. 17, February 1996, pp. 22-33.

ARSÉNIO NunES, João, «Sobre alguns aspectos da evolução política do Partido Comunista Português após a reorganização de 1929 (1931-33)», Análise Social, vol. XVIII (67-68), 1981, pp. 715-731.

Bueno, Manuel, GÁlveZ, Sergio, «Un paso más en el processo de «normalizaciín historiográfica» de la historia del PCE», Cuadernos de História Contemporânea, vol. 27, 2005, 317-322.

CARvalho, Filipe, «Bandeira Vermelha, órgão da Federação Maximalista (1919-21)», História, May, 1983, pp. 6-13.

CAstro, Armando, «Primeiros críticos de Marx em Portugal», Vértice, vol. XLII, pp. 16-27.

Cruz Martinez, Rafael, «La organización del PCE (1920-1934)», Estudios de historia social, n. ${ }^{\circ}$ 31, 1984, pp. 223-312.

Cruz Martinez, Rafael, «Del partido recién llegado al partido de todos. El PCE, 1920-1939»; em BUENO, Manuel, HinojosA, José, García, Carmen (coords.), Historia del PCE. I Congreso 1920-1977, Vol. I, Fundación de Investigaciones Marxistas, 2007, pp. 143-158.

CRUZ, Rafael, El Partido Comunista de España en la Segunda República, Alianza Editorial, Madrid, 1987.

Cunhal, Álvaro, O Partido com Paredes de Vidro, 6. edição, Edições Avante!, Lisboa, 2002.

Elorza, Antonio; BizCARrondo, Marta, Queridos Camaradas: La Internacional Comunista y España, 1919-1939, Editorial Planeta, Barcelona, 1999.

FARrÉ, Juan Avilés, La fe que vino de Rusia: la revolución bolchevique y los españoles (1917-1931), Universidad Nacional de Educación a Distancia, Madrid, 1999.

FreIRE, João, «Bento Gonçalves - O fundador ideológico do PCP», História, May, 1985, pp.14-21.

GonçAlves, Bento, Palavras Necessárias - A vida proletária em Portugal de 1872 a 1927, Câmara Municipal de Montalegre, Montalegre, 2000.

Gonçalves, Bento, Os Comunistas, A Opinião, Porto, 1976.

Gutiérrez-Álvvarez, Pepe, PAgÈs, Pelai (dirs.), La revolución rusa pasó por aquí, Laertes, Barcelona, 2017.

Hermet, Guy, Los comunistas en España, Paris, Ruedo Ibérico, 1967. 
Humbert-Droz, Jules, De Lénine à Staline. Dix ans au service de l'Internationale communiste, 1921-1931, Éd. De la Baconnière, Neuchâtel, 1971.

MADEIRA, João, «Bolchevização, funcionários clandestinos e identidade no PCP», Revista da História das Ideias, vol. 25, 2004, 507-532.

MadeIRA, João, História do PCP, Tinta da China, Lisboa, 2013.

Margarido, Alfredo, A introdução do marxismo em Portugal 1850-1930, Guimarães Editores, Lisboa, 1976.

Oliveira, César, O Primeiro Congresso do Partido Comunista Português, Seara Nova, Lisboa, 1975.

PACHeCo Pereira, José, «Bibliografia sobre o movimento operário português desde a origem até 24 de Abril de 1974», Análise Social, vol. XVII (67-68), 1981, pp. 989-1011.

PACHeCo PereIRA, José, «Contribuição para a história do Partido Comunista Português na I República (1921-26)», Análise Social, vol. XVII (67-68), 1981, pp. 695-713.

Pacheco Pereira, José, Álvaro Cunhal - «Daniel», o jovem revolucionário, vol. I, Círculo de Leitores, Lisboa, 1999.

PACHECo PEREIRA, José, Questões sobre o movimento operário português e a revolução russa de 1917, Edição do autor, Porto, 1971.

PALA, Giaime, «El Partido y la ciudad. Modelos de organización y militância del PSUC clandestino (1963-1975)», História Contemporânea, no. 50, 2015 , 195-222.

PITA, António Pedro, «A recepção do marxismo pelos intelectuais portugueses (1930-1941)», Centro de Estudos Sociais de Coimbra, no. 12, July 1989, pp.1-29.

PITA, António Pedro, «O Marxismo na Constituição Ideológica e Política do Partido Comunista Português», Revista Crítica de Ciências Sociais, no. 40, October 1994, pp. 89-108.

Quintela, João G.P., Para a história do movimento comunista em Portugal: 1. A construção do Partido (1. . Período 1919-1929), Edições Afrontamento, Porto, 1976.

StANEK, O., «Humbert-Droz, Jules, De Lénine à Staline. Dix ans au service de l'Internationale communiste, 1921-1931, Éd. De la Baconnière, Neuchâtel, 1971, Études internationales, 3(3), 1972, p.425.

STDOuRDzÉ, Yves, «Humbert-Droz, De Lénine à Staline: Diz ans au service de 1'Internacionale communiste, 1921-193», L'Homme et la soviété, n. ${ }^{\circ} 2$, 1973, pp.196-199.

VEntura, António, «Algumas notas sobre a imprensa comunista em Portugal (1919-1921)», Seara Nova, no. 1580, June 1977, pp.10-12.

Ventura, António, Anarquistas, republicanos e socialistas em Portugal - As convergências possíveis (1892-1920), Edições Cosmos, Lisboa, 2000. 


\section{Notes on contributor}

Historian, professor of Contemporary History and Journalism, and ProRector of the Universidade Europeia, Lisbon, Portugal. He graduated in History at Universidade Lusíada, Lisbon, Portugal, and has a doctorate, with distinction and honour unanimously, in Contemporary History at the Universidade de Lisboa, with the thesis "Os Comunistas Portugueses no Exílio (1960-1974). He is the author of the books: "A Ascensão ao Poder de Cavaco Silva" (Edeline, 2005); "Álvaro Cunhal - Retrato Pessoal e Íntimo» (Esfera dos Livros, 2010) - integrated into the National Reading Plan; "António Guterres - Os Segredos do Poder» (Alêtheia, 2013); "Os Filhos da Clandestinidade» (Esfera dos Livros, 2016) e "Júlio de Melo Fogaça - Biografia» (Edições Desassossego, 2018) - national top sales. The research work of Adelino Cunha focuses on the study of communism in Portugal. 